\title{
Root and shoot attributes of indigenous perennial accessions of the wild mungbean (Vigna radiata ssp. sublobata)
}

\author{
G. J. Rebetzke ${ }^{\mathrm{A}}$ and R. J. Lawn ${ }^{\mathrm{B}, \mathrm{C}}$

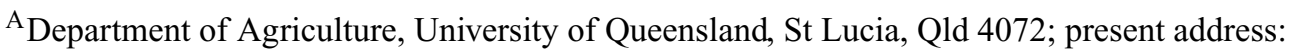 \\ CSIRO Plant Industry, PO Box 1600, Canberra, ACT 2601, Australia. \\ ${ }^{\mathrm{B}}$ School of Tropical Biology, James Cook University, Townsville, Qld 4811 and \\ CSIRO Sustainable Ecosystems, Davies Laboratory, Townsville, Qld 4814, Australia. \\ ${ }^{\mathrm{C}}$ Corresponding author. Email: robert.lawn@jcu.edu.au
}

\begin{abstract}
Root and shoot attributes of 12 indigenous perennial accessions of the wild mungbean (Vigna radiata ssp. sublobata) were evaluated in early and late summer sowings in the field in SE Queensland. All but one of the accessions were obtained from the Townsville-Charters Towers region of NE Queensland. In both sowings, the accessions developed thickened tap and lateral roots, the taproot thickening extending to a depth of $0.20-0.30 \mathrm{~m}$ below the soil surface, depending on accession. The thickened lateral roots emerged from the taproot within $0.10 \mathrm{~m}$ of the soil surface, and extended laterally up to $1.10 \mathrm{~m}$, remaining close to the soil surface. Differences among the accessions in gross root morphology and phenology were relatively small. There were differences among the accessions in the production of seed, tuberised root, and recovered total plant biomass. Depending on accession and sowing date, the tuberised roots accounted for up to $31 \%$ of recovered plant biomass and among accessions, the root biomass was positively correlated with total plant biomass. In contrast, seed biomass represented only a small proportion of recovered plant biomass, up to a maximum of $14 \%$, depending on accession and sowing date. Among accessions, the proportion of seed biomass tended to be negatively correlated with that of tuber biomass. The perennial trait appears to be unique to Australian accessions of wild mungbean obtained from coastal-subcoastal, speargrass-dominant woodlands of NE Queensland. Although the ecological significance of the trait remains conjectural, field observation indicates that it facilitates rapid plant re-growth following early summer rainfall, especially where dry-season fire has removed previous-season above-ground growth.
\end{abstract}

Additional keywords: bush tucker, environmental adaptation, legume germplasm, root tubers.

\section{Introduction}

The wild mungbean (Vigna radiata ssp. sublobata) is one of several indigenous Vigna taxa found across tropical and subtropical Australia (Lawn and Watkinson 2002). The subspecies is the putative wild progenitor of the cultivated mungbean ( $V$. radiata ssp. radiata) (Smartt and Hymowitz 1985). Australian forms of the subspecies are generally more gracile than those found in Asia and intervening islands. Nonetheless, Australian accessions can be hybridised readily with the cultivated mungbean, the progeny demonstrating normal inheritance for a range of qualitative and quantitative traits (James et al. 1999).

A study of wild mungbean accessions collected from a wide range of geographical locations in northern Australia and grown in the field in SE Queensland (Lawn and Rebetzke 2006), identified several perennial accessions possessing thickened tap and lateral roots, which contrasted with the fine, fibrous root system normally observed in the species. In their natural habitat, the thickened tuberous roots have been observed to give rise to adventitious subterranean shoots that emerged with the first summer rains, or after fires towards the end of the dry season (Lawn and Cottrell 1988). The tuberous roots enable the plants to persist vegetatively from season to season.

The development of thickened tap and/or lateral roots to produce tubers or similar structures is a common adaptation among plants, enabling survival of environmental stresses caused by a range of biotic (e.g. predation, grazing) and abiotic (e.g. fire, frost, and drought) factors (Rundel 1983). The tuberous organs provide a source for adventitious buds and permit below-ground storage of assimilate to enable rapid regeneration after stresses are relieved. Although other indigenous Vigna species such as V. lanceolata and V. vexillata are tuberous rooted perennials (Grant et al. 2003; 
Lawn and Holland 2003), root tuberisation in $V$. radiata appears to be unique to some indigenous Australian forms of the wild subspecies.

The purpose of the present study was to document variation in root and shoot morphological traits among several accessions of $V$. radiata ssp. sublobata that had been observed to perenniate through the development of thickened, tuberous roots.

\section{Materials and methods}

\section{Germplasm}

Twelve tuberous rooted accessions of $V$. radiata ssp. sublobata were selected (Table 1), based on observations on cultivated plants in southeastern Queensland (Lawn and Rebetzke 2006). Although the entire collection sampled locations across northern Australia from northern coastal NSW to the Kimberley (Lawn and Watkinson 2002), all but one of the perennial accessions had been collected in the Charters TowersTownsville region (Fig. 1). The exact collection location of ACC 30, the one accession not obtained from this region, is not known but was recorded as 'Cape York somewhere' when the seed was committed to storage in the $1960 \mathrm{~s}$.

\section{Experimental design and cultivation}

The 12 perennial accessions were grown in the field at the CSIRO Samford Pasture Research Station, at 2 sowing dates (15 December and 16 February) to examine their growth and development in response to climatic conditions experienced by plants emerging in early and late summer. Plots were arranged in a randomised complete block design with 2 replicates of each of the 2 sowings. Each plot was 2.2 by $2.2 \mathrm{~m}$ in size, with 2 guard rows of black gram $(V$. mungo $) \mathrm{cv}$. Regur around the perimeter of each sowing.

Cultural details of the plots are available in Rebetzke (1994). Briefly, the experimental area was cultivated and treated with superphosphate fertiliser ( $40 \mathrm{~kg} \mathrm{P} / \mathrm{ha})$. Scarified seeds were inoculated with commercial rhizobium inoculant strain CB1015 (cowpea strain) and sown at a depth of $0.01 \mathrm{~m}$ in a row centred down the middle of each plot to allow for the trailing nature of the plants. The plots were irrigated immediately after sowing to promote germination, and seedlings thinned to 10 plants per linear $\mathrm{m}$ after establishment. Plots were maintained free of weeds, irrigated during occasional dry periods, and sprayed as necessary to control insects and disease, to provide conditions favourable for plant growth. The plants grew vigorously and were trimmed fortnightly to constrain their lateral spread to within the defined plot area.

\section{Attributes measured}

Several attributes describing root morphology were measured, together with selected shoot and phenological traits. The following root traits were measured after final seed harvest on 3 random plants carefully excavated from each plot.

(a) Tap root:

(i) diameter at ground level;

(ii) length of tap root exceeding $2 \mathrm{~mm}$ diameter.

(b) Lateral roots:

(i) depth beneath the soil surface of the junction of the tap and the first thickened lateral root;

(ii) number of thickened lateral roots exceeding $2 \mathrm{~mm}$ diameter when measured $10 \mathrm{~mm}$ from the junction with the tap root;

(iii) length of thickened lateral roots exceeding $2 \mathrm{~mm}$ diameter.

Phenological traits recorded were the dates of flowering $(50 \%$ of plants with at least 1 flower) and of pod maturity ( $95 \%$ of pods mature), whence the durations from sowing to flowering (the vegetative phase), from flowering to pod maturity (the reproductive phase), and sowing to pod maturity (total growth cycle) were calculated. Shoot traits were stem length (soil surface to uppermost node, $\mathrm{mm}$ ) at 6 weeks after sowing, growth habit (rating scale of $1-4$, where $1=$ erect, $4=$ prostrate), and the above-ground biomass $\left(\mathrm{g} / \mathrm{m}^{2}\right)$ and seed biomass $\left(\mathrm{g} / \mathrm{m}^{2}\right)$ at pod maturity.

Estimates of dry tuber biomass were obtained by excavating a $2.0 \mathrm{~m}$ by $0.5 \mathrm{~m}$ quadrat located randomly over the sowing row to a depth of $0.3 \mathrm{~m}, 198$ and 134 days after sowing, for sowing 1 and 2, respectively. All tuberised roots were carefully removed, washed free of soil, dried at $60^{\circ} \mathrm{C}$, and weighed. Finer roots were not recovered. The seed harvest index $\left(\mathrm{HI}_{\text {seed }}\right)$ and the tuber harvest index $\left(\mathrm{HI}_{\text {tuber }}\right)$ were calculated as the respective proportions of the recovered total plant biomass present as seed and tuber at pod maturity.

The tubers from a subset of the accessions harvested from the 16 February sowing were analysed for protein content using the Kjeldahl procedure, where protein content $(\%$, dry weight basis) was estimated as $6.25 \times$ nitrogen concentration $(\%$, dry weight basis).

\section{Results and discussion}

All accessions grew vigorously in the early summer sowing, and initially in the late summer sowing. However, growth was

Table 1. Provenance information for 12 perennial accessions of $\boldsymbol{V}$. radiata ssp. sublobata used in the study

\begin{tabular}{llccc}
\hline Accession & Location & Latitude & Longitude & Altitude (m) \\
\hline ACC 2 & Castle Hill, Townsville & $19^{\circ} 13^{\prime} \mathrm{S}$ & $146^{\circ} 48^{\prime} \mathrm{E}$ & 100 \\
ACC 3 & Nelly Bay, Magnetic Island & $18^{\circ} 12^{\prime} \mathrm{S}$ & $147^{\circ} 25^{\prime} \mathrm{E}$ & 2 \\
ACC 22 & Keelbottom Ck crossing, Hervey's Range Rd & $19^{\circ} 38^{\prime} \mathrm{S}$ & $146^{\circ} 17^{\prime} \mathrm{E}$ & 400 \\
ACC 25 & Fanning River & $19^{\circ} 44^{\prime} \mathrm{S}$ & $146^{\circ} 26^{\prime} \mathrm{E}$ & 250 \\
ACC 26 & Mingela Range & $19^{\circ} 53^{\prime} \mathrm{S}$ & $146^{\circ} 40^{\prime} \mathrm{E}$ & 200 \\
ACC 30 & 'Cape York' & $-\mathrm{A}$ & $-\mathrm{A}$ \\
ACC 87 & Woodstock, near Lansdown & $19^{\circ} 42^{\prime} \mathrm{S}$ & $146^{\circ} 50^{\prime} \mathrm{E}$ & 170 \\
ACC 88 & Mingela Range & $19^{\circ} 53^{\prime} \mathrm{S}$ & $146^{\circ} 32^{\prime} \mathrm{E}$ & 200 \\
ACC 89 & Mingela-Ravenswood Rd & $19^{\circ} 56^{\prime} \mathrm{S}$ & $146^{\circ} 42^{\prime} \mathrm{E}$ & 200 \\
ACC 90 & Charters Towers & $20^{\circ} 03^{\prime} \mathrm{S}$ & $146^{\circ} 18^{\prime} \mathrm{E}$ & 250 \\
ACC 91 & Near Townsville & $19^{\circ} 21^{\prime} \mathrm{S}$ & $146^{\circ} 52^{\prime} \mathrm{E}$ & 10 \\
ACC 92 & Near Hillsborough Stud Station & $20^{\circ} 02^{\prime} \mathrm{S}$ & $147^{\circ} 00^{\prime} \mathrm{E}$ & 100 \\
\hline
\end{tabular}

${ }^{\mathrm{A}}$ Exact provenance details not known for this accession. 


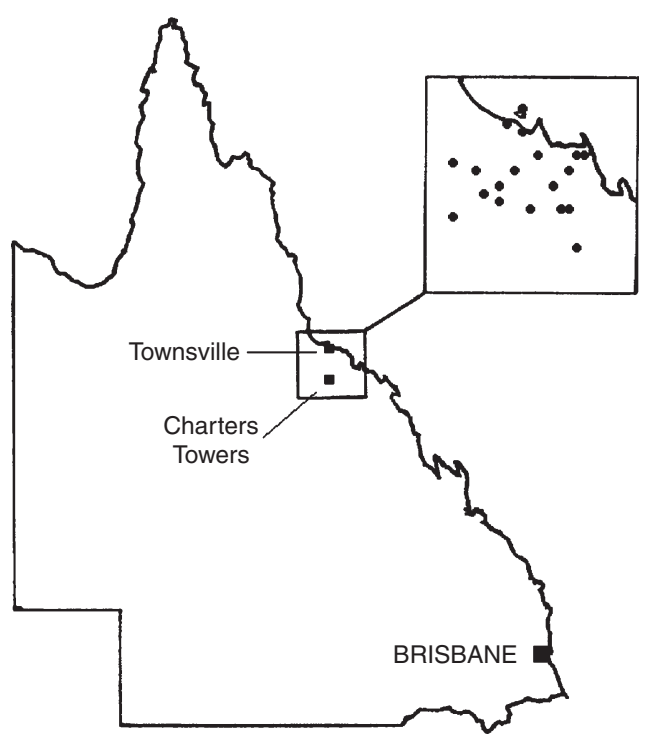

Fig. 1. Sites from where indigenous perennial accessions of V. radiata ssp. sublobata were collected (based on the study of Lawn and Rebetzke 2006).

constrained towards the end of the growth cycle in the late summer sowing, presumably by cool autumn temperatures. A separate nearby study with a diversity of annual and perennial accessions (Rebetzke and Lawn 2006b) indicated that although leaf growth of all accessions was sensitive to the cooler autumn temperatures in the subtropics, the effect was most pronounced in accessions from the tropics.

\section{Root morphology}

All 12 accessions developed a strong, thickened tap root with well-developed lateral roots in the surface layers of the soil (Fig. 2a). Generally, the thickened lateral roots emerged from the taproot at relatively shallow depths and extended laterally just below the soil surface for some distance from the plant. By contrast, there was no evidence of any thickened roots in annual accessions sampled in immediately adjacent studies (data not shown).

All the accessions produced thickened tap and lateral roots in both the 15 December and 16 February sowings. There were significant differences between the 2 sowing dates for root traits except taproot length (Table 2). The magnitudes of most traits were larger at the first sowing date, as were the differences between accessions, presumably because the longer growth duration in the first sowing enabled the genotypic differences to be better expressed. There were significant accession $\times$ sowing date interactions for some traits. However, these arose primarily because differences between accessions were compressed at the second sowing.

There were no significant genotypic differences in mean stem diameter at the soil surface, which declined from
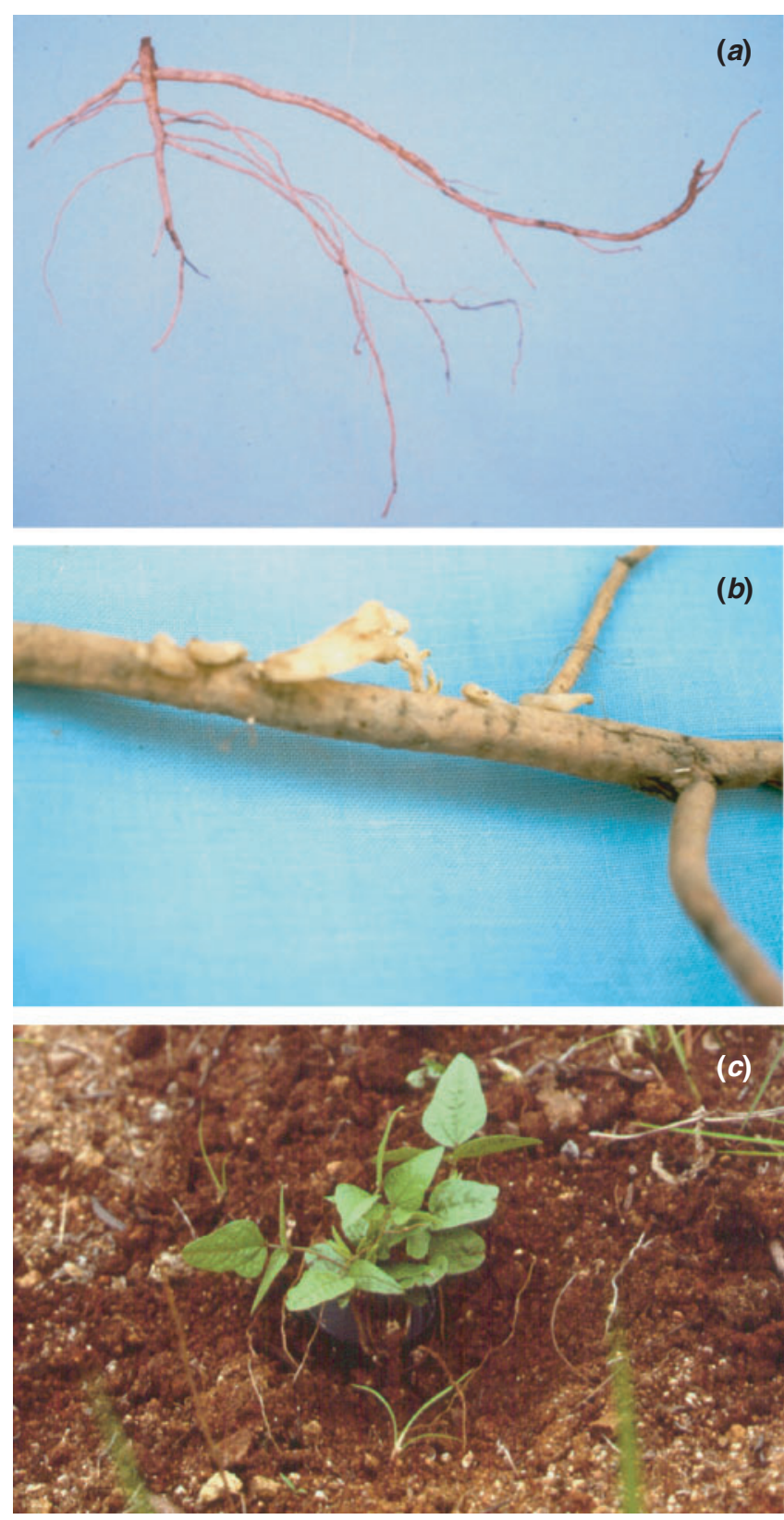

Fig. 2. Root tuberisation in ACC 87, a perennial accession of V. radiata ssp. sublobata collected from Woodstock, west of Townsville. (a) Gross morphology showing thickened laterals; (b) close-up of a thickened lateral showing emerging adventitious shoot buds; (c) adventitious shoots emerging from the soil after fire and then early summer rain.

an average $9.0 \mathrm{~mm}$ at the first sowing to $5.9 \mathrm{~mm}$ at the second (Table 2). The average length of taproot exceeding $2 \mathrm{~mm}$ in diameter varied among accessions $(P \leq 0.01)$ from $204 \mathrm{~mm}$ in ACC 26 to $296 \mathrm{~mm}$ in ACC 2. However, it is not clear whether these differences were sufficient to be of adaptive significance, at least in terms of thickened lateral root development. 
Table 2. Stem diameter at ground level, length of thickened taproot, and attributes of the thickened lateral roots for 12 perennial accessions of $V$. radiata ssp. sublobata

Accession means are from 3 plants from each of 2 replicates at 2 sowing dates

\begin{tabular}{|c|c|c|c|c|c|c|c|}
\hline Accession & $\begin{array}{l}\text { Stem diam. } \\
\quad(\mathrm{mm})\end{array}$ & $\begin{array}{c}\text { Tap root } \\
\text { length } \\
(\mathrm{mm})\end{array}$ & $\begin{array}{l}\text { Depth of the } \\
\text { 1st thickened } \\
\text { lateral (mm) }\end{array}$ & $\begin{array}{c}\text { Mean no. of } \\
\text { thickened laterals } \\
\text { (per plant) }\end{array}$ & $\begin{array}{l}\text { Total length of } \\
\text { thickened laterals } \\
\text { per unit area } \\
\left(\mathrm{mm} / \mathrm{m}^{2}\right)\end{array}$ & $\begin{array}{l}\text { Longest } \\
\text { thickened } \\
\text { lateral } \\
(\mathrm{mm})\end{array}$ & $\begin{array}{l}\text { Mean length of } \\
\text { thickened } \\
\text { laterals } \\
(\mathrm{mm})\end{array}$ \\
\hline ACC 2 & 7.2 & 296 & 38 & 3.9 & 1127 & 508 & 291 \\
\hline ACC 3 & 7.4 & 271 & 30 & 4.4 & 1158 & 533 & 257 \\
\hline ACC 22 & 7.5 & 260 & 26 & 4.6 & 1108 & 483 & 238 \\
\hline ACC 25 & 7.9 & 213 & 36 & 3.2 & 1131 & 625 & 350 \\
\hline ACC 26 & 8.0 & 204 & 42 & 3.9 & 990 & 425 & 248 \\
\hline ACC 30 & 7.9 & 248 & 27 & 4.2 & 1387 & 558 & 332 \\
\hline ACC 87 & 7.2 & 267 & 32 & 4.8 & 1930 & 667 & 400 \\
\hline ACC 88 & 6.9 & 265 & 27 & 3.8 & 941 & 377 & 248 \\
\hline ACC 89 & 7.0 & 269 & 26 & 3.6 & 1503 & 625 & 420 \\
\hline ACC 90 & 7.7 & 279 & 35 & 2.6 & 937 & 408 & 358 \\
\hline ACC 91 & 7.9 & 285 & 28 & 4.7 & 1955 & 642 & 412 \\
\hline ACC 92 & 7.1 & 238 & 27 & 4.8 & 1282 & 433 & 266 \\
\hline 15 Dec. & 9.0 & 256 & 27 & 4.7 & 1921 & 724 & 426 \\
\hline 16 Feb. & 5.9 & 260 & 35 & 3.1 & 660 & 297 & 222 \\
\hline \multicolumn{8}{|c|}{ Standard error of differences between: } \\
\hline Accessions & 0.67 n.s. & $25^{* *}$ & $7.0^{*}$ & $1.2^{* *}$ & $284^{* *}$ & $101^{* *}$ & $62^{* *}$ \\
\hline Dates & $0.24^{* *}$ & 10 n.s. & $2.9^{*}$ & $0.20^{* *}$ & $72^{* *}$ & $22^{* *}$ & $12^{* *}$ \\
\hline
\end{tabular}

${ }^{*} P \leq 0.05 ;{ }^{* *} P \leq 0.01 ;$ n.s., not significant.

In all the accessions, the uppermost thickened lateral root originated close (between 0.026 and $0.042 \mathrm{~m}$ ) to the soil surface (Table 2). With the delay in sowing, the average depth of the first thickened lateral root was slightly greater $(P \leq 0.05)$. There were no significant differences among accessions in the length of the zone of taproot from which thickened laterals emerged (data not shown). Most of the laterals emerged within $0.10 \mathrm{~m}$ of the soil surface and remained close to the soil surface throughout their length. Presumably, close proximity of the root to the soil surface facilitates the emergence and growth of adventitious shoots in subsequent seasons (cf. Fig. 2b).

There were significant differences $(P \leq 0.01)$ between accessions in the number of thickened laterals per plant, the length of thickened laterals per unit area, the longest thickened laterals, and the average length of the thickened laterals (Table 2). Those accessions with the greatest length per $\mathrm{m}^{2}$ of thickened laterals (e.g. ACC91, ACC 87) tended to have more and longer thickened laterals, whereas those with the smallest length per $\mathrm{m}^{2}$ (e.g. ACC 88, ACC 90) had fewer, shorter thickened laterals.

Indeed, the genotypic means for the length per $\mathrm{m}^{2}$ of thickened lateral roots were positively correlated with genotypic means for the average length of the individual laterals $\left(r=0.75^{* *}\right)$, for the length of the longest laterals $\left(r=0.80^{* *}\right)$, and for the number of thickened laterals $\left(r=0.57^{*}\right)$. That is, there was no evidence that genotypes with fewer thickened laterals had longer laterals. There was also no apparent association between genotypic differences in the taproot length and any of the lateral root traits.
The standard errors for the differences between means of the root traits were generally large (Table 2), reflecting large intra-plot variability among plants within each accession. For example, the coefficient of variation for the length of the zone of taproot from which the thickened lateral roots emerged was $43 \%$. The length of the individual thickened lateral roots was highly variable from plant to plant (ranging from 10 to $1100 \mathrm{~mm}$ ), in part because in some instances, the distal ends of the roots had died off by the time the plots were sampled.

Indeed, up to $10 \%$ of the plants in each plot had died before the roots were sampled. The dead plants had produced thickened roots similar to those of the surviving plants but these had failed to persist, presumably reflecting lack of adaptation to the cool, wet autumn of the subtropical environment where the study was conducted. Variable persistence between plants was noted for the related tuberous perennial species, $V$. lanceolata, when grown at the same location (Lawn and Holland 2003).

There was also no evidence of either above- or belowground adventitious shoots in the current study, in contrast to previous studies in the same environment (Lawn and Rebetzke 2006) where adventitious shoots were abundant below ground on thickened tap and lateral roots (Fig. 2b), as well as above ground beneath the cotyledonary nodes. Presumably, the difference was due to the fact that sampling in the current study occurred in the early winter when plants were dormant and growth was suppressed by cool temperatures. 


\section{Phenology and growth habit}

Averaged over sowing dates, the differences between accessions for time to flowering and for the durations of reproductive growth and the total growth cycle were small and non-significant $(P>0.05)$. Nonetheless, all accessions were late flowering and of much longer growth duration than would be expected for mungbean cultivars. The relatively small overall variation among the accessions may have partly reflected their similar provenance (Fig. 1). Other studies
(Lawn and Rebetzke 2006; Rebetzke and Lawn 2006a) have shown that phenological differences among accessions, particularly in time to flowering, are due to differential sensitivity to photo-thermal environment, which in turn relates to their latitude of adaptation.

Later sowing generally extended the time to flowering but substantially reduced the duration of the reproductive phase (Table 3). The consequence was that without exception, later sowing shortened the duration of the growth cycle.

Table 3. Phenology and growth habit of 12 perennial accessions of $V$. radiata ssp. sublobata for earlyand late-summer sowings in SE Queensland

Phenology: f, days to flowering; $p$, days from flowering to pod maturity; $m$, days from sowing to pod maturity. 1 , erect; 4 , prostrate; -, not measured for this sowing. Data are means across replicates in each sowing

\begin{tabular}{|c|c|c|c|c|c|c|}
\hline Accession & Date of sowing & f(days) & $\mathrm{p}$ (days) & $\mathrm{m}$ (days) & $\begin{array}{l}\text { Stem length } \\
(\mathrm{mm})\end{array}$ & $\begin{array}{l}\text { Growth habi } \\
\quad(1-4)\end{array}$ \\
\hline \multirow[t]{2}{*}{ ACC 2} & $15 \mathrm{Dec}$. & 87.5 & 91.5 & 179.0 & 15.5 & 3.3 \\
\hline & 16 Feb. & 86.0 & 46.5 & 133.0 & 23.2 & - \\
\hline Mean over dates & & 86.8 & 69.0 & 156.0 & 19.4 & \\
\hline \multirow[t]{2}{*}{ ACC 3} & 15 Dec. & 84.0 & 96.0 & 180.0 & 17.7 & 4.0 \\
\hline & 16 Feb. & 86.0 & 44.0 & 130.0 & 22.7 & - \\
\hline Mean over dates & & 85.0 & 70.0 & 155.0 & 20.2 & \\
\hline \multirow[t]{2}{*}{ ACC 22} & 15 Dec. & 81.5 & 94.5 & 176.0 & 17.9 & 3.0 \\
\hline & 16 Feb. & 98.0 & 30.0 & 128.0 & 17.9 & - \\
\hline Mean over dates & & 89.8 & 62.3 & 152.0 & 17.9 & \\
\hline \multirow{2}{*}{ ACC 25} & $15 \mathrm{Dec}$. & 80.5 & 99.5 & 180.0 & 20.0 & 3.0 \\
\hline & 16 Feb. & 102.0 & 40.5 & 143.0 & 22.5 & - \\
\hline Mean over dates & & 91.3 & 70.0 & 161.5 & 21.3 & \\
\hline \multirow[t]{2}{*}{ ACC 26} & 15 Dec. & 82.5 & 97.5 & 180.0 & 17.5 & 3.0 \\
\hline & 16 Feb. & 103.5 & 39.0 & 143.0 & 22.2 & - \\
\hline Mean over dates & & 93.0 & 68.3 & 161.5 & 19.9 & \\
\hline \multirow[t]{2}{*}{ ACC 30} & $15 \mathrm{Dec}$. & 80.0 & 98.0 & 178.0 & 19.2 & 3.0 \\
\hline & 16 Feb. & 98.5 & 34.5 & 133.0 & 22.9 & - \\
\hline Mean over dates & & 89.3 & 66.3 & 155.5 & 21.1 & \\
\hline \multirow[t]{2}{*}{ ACC 87} & 15 Dec. & 77.0 & 103.0 & 180.0 & 16.5 & 3.0 \\
\hline & 16 Feb. & 106.0 & 36.5 & 143.0 & 24.5 & - \\
\hline Mean over dates & & 91.5 & 69.8 & 161.5 & 20.5 & \\
\hline \multirow{2}{*}{ ACC 88} & 15 Dec. & 74.5 & 104.5 & 179.0 & 17.5 & 3.0 \\
\hline & 16 Feb. & 102.5 & 22.5 & 125.0 & 20.0 & - \\
\hline Mean over dates & & 88.5 & 63.5 & 152.0 & 18.8 & \\
\hline \multirow[t]{2}{*}{ ACC 89} & 15 Dec. & 76.5 & 103.5 & 180.0 & 20.9 & 3.0 \\
\hline & 16 Feb. & 90.0 & 40.0 & 130.0 & 21.0 & - \\
\hline Mean over dates & & 83.3 & 71.8 & 155.0 & 21.0 & \\
\hline \multirow[t]{2}{*}{ ACC 90} & 15 Dec. & 78.5 & 101.5 & 180.0 & 16.7 & 3.3 \\
\hline & 16 Feb. & 96.0 & 41.5 & 138.0 & 18.5 & - \\
\hline Mean over dates & & 87.3 & 71.5 & 159.0 & 17.6 & \\
\hline \multirow{2}{*}{ ACC 91} & 15 Dec. & 91.0 & 83.5 & 175.0 & 22.2 & 3.0 \\
\hline & 16 Feb. & 97.0 & 45.5 & 143.0 & 28.7 & - \\
\hline Mean over dates & & 94.0 & 64.5 & 159.0 & 25.5 & \\
\hline \multirow{2}{*}{ ACC 92} & 15 Dec. & 80.0 & 94.5 & 175.0 & 19.4 & 3.3 \\
\hline & 16 Feb. & 95.0 & 47.5 & 143.0 & 19.3 & - \\
\hline Mean over dates & & 87.5 & 71.0 & 159.0 & 19.4 & \\
\hline \multirow[t]{2}{*}{ Date means } & 15 Dec. & 81.1 & 97.3 & 178.5 & 18.4 & 3.2 \\
\hline & 16 Feb. & 96.7 & 39.0 & 136.0 & 22.0 & - \\
\hline Overall mean & & 88.9 & 68.1 & 157.3 & 20.2 & - \\
\hline \multicolumn{7}{|c|}{ Standard errors of differences between: } \\
\hline \multicolumn{2}{|l|}{ Accessions } & 6.7 n.s. & 8.2 n.s. & 5.2 n.s. & $2.0^{*}$ & $0.2^{*}$ \\
\hline \multicolumn{2}{|l|}{ Sowing dates } & $2.7^{* *}$ & $3.4^{* *}$ & $2.1^{* *}$ & $0.8^{*}$ & - \\
\hline \multicolumn{2}{|c|}{ Accessions within sowing dates } & $4.8^{* *}$ & $7.9^{* *}$ & $6.0^{* *}$ & $2.6^{* *}$ & - \\
\hline
\end{tabular}

${ }^{*} P \leq 0.05 ;{ }^{* *} P \leq 0.01 ;$ n.s., not significant. 
Nonetheless, there was a large differential response to sowing date $(P \leq 0.01)$ among the accessions for the time to flowering and the duration of reproductive growth. The main difference was that flowering of the 3 coastal accessions, ACC 2, ACC 3, and to a lesser extent ACC 91, was not delayed by the later sowing, whereas flowering of some of the accessions obtained further inland, e.g. ACC 25, ACC 26, ACC 27, and ACC 88, was delayed considerably. The three coastal accessions were among the latest flowering in the first sowing, but were relatively earlier flowering at the second sowing.

The tendency for early-summer sowings of inland accessions to be earlier flowering than coastal accessions from the same latitude has been observed in other Vigna species (Grant et al. 2003; Lawn and Holland 2003). This may reflect the fact that the duration of the wet season is usually shorter and more variable further inland, so that late flowering genotypes are potentially more vulnerable in drier years. The adaptive significance of the differential responses to sowing date between the coastal accessions and those obtained further inland was not readily apparent but may reflect differential genotypic responses to photothermal conditions.

There was some variation $(P \leq 0.05)$ among the 12 accessions for stem length and growth habit, measured at 6 weeks after sowing (Table 3). Stem length at 6 weeks was greater for ACC 91 than for the other accessions, and in the second than the first sowing. The growth habit of ACC 3 was more prostrate than of the other accessions. The terminal leaflet of ACC 3 was also deeply lobed (data not shown), contrasting to the more common sublobate leaflet shape observed in the other accessions.

\section{Plant, tuber, and seed dry matter production}

Averaged over sowing dates, the recovered total plant biomass (above + below-ground dry matter), and tuberised root and seed dry matter varied significantly $(P \leq 0.01)$ among accessions and between sowing dates (Table 4$)$. At the first sowing date, average biomass production was equivalent to $3.4 \mathrm{t} / \mathrm{ha}$, with a $60 \%$ range among accessions. The variation in biomass was greater than that observed for phenology (Table 3), but was smaller than the range in biomass production for the collection of Australian accessions as a whole, when grown under generally similar conditions (Lawn and Rebetzke 2006). Average seed production was small, especially from the late summer sowing when most accessions produced only traces of seed. Average tuber biomass was 3 times that for seed, with an average of $20 \%$ of the final biomass in the tubers in the first sowing date (Table 4).

Among accessions, those producing greater total biomass also produced more tuber biomass and a greater proportion of tuber biomass. Indeed, averaged over sowing dates, there were positive correlations between tuber biomass and total biomass $\left(r=0.76^{*}\right)$ and between tuber biomass and $\mathrm{HI}_{\text {tuber }}\left(r=0.95^{* *}\right)$. Seed production was correlated with $\mathrm{HI}_{\text {seed }}\left(r=0.61^{*}\right)$, but not total biomass. There was a trend for accessions with higher $\mathrm{HI}_{\text {seed }}$ to have lower $\mathrm{HI}_{\text {tuber }}(r=-0.52, P<0.10)$.

The effect of sowing date on seed yield, tuberised root, and total biomass (Table 4 ) was large and highly significant $(P<0.001)$. Of the 3 traits, total biomass was least affected by sowing date, decreasing approximately $40 \%$ on average when sowing was delayed. In contrast, average seed yield was reduced by $98 \%$ with later sowing. The reduction in seed yield coincided with the shortening in the duration of reproductive growth as sowing was delayed (cf. Table 3 ). The delay in sowing reduced tuber biomass by up to $85 \%$, reflecting reductions in both total biomass and in $\mathrm{HI}_{\text {tuber }}$ (Table 4). There were small but significant accession $\times$ sowing date interaction effects for most traits, largely because differences among accessions were compressed in the later sowing.

The relatively greater reduction in tuber biomass than total biomass with delayed sowing may arise because tuberisation is not initiated until plants have been growing for some time. This interpretation was supported by data from a separate study in which the perennial accession ACC 87 was sown at approximately 3-week intervals from November to April (see Rebetzke and Lawn $2006 b$ for experimental details). As sowing was delayed and growth duration was shortened, tuber biomass declined from a maximum 126 to $0.2 \mathrm{~g} / \mathrm{m}^{2}$ when sown 138 days later. When tuber biomass was expressed as a function of growth duration at the different sowing dates, it appeared that little tuber biomass was accumulated for growth durations of less than 90 days, whereas beyond about 115 days, tuber biomass increased almost linearly with longer growth duration (Fig. 3).

This pattern would be broadly consistent with species such as potato (Solanum tuberosum) and yam (Dioscorea rotundata), where following initiation tuber weight increases curvilinearly (potatoes, Milthorpe 1967) or sigmoidally (yam, Sobulo 1972) with the duration of growth. Additionally, the observed reductions in tuber biomass (Table 4, Fig. 1) may have arisen because later sowing(s) delayed tuber growth into cooler autumn temperatures. While shorter days enhanced tuber initiation and development in yam beans (Pachyrrhizus spp.), cool aerial temperatures substantially reduced tuber dry weight (Paull et al. 1988; Alvarenga and Valio 1989).

Whatever the cause, the reduction in tuber biomass with delayed sowing was relatively smaller than that in seed biomass (Table 4), which may indicate that tuber formation is relatively more important for survival and reproductive success of the perennial accessions when emergence occurs later, e.g. in seasons where the monsoonal summer rains arrive late. Consistent with this interpretation, a comparison of the responses of the 12 perennial accessions in this study with the responses of 10 annual accessions sown at the same 
Table 4. Production of seed, tuber, and recovered total biomass (above + below ground) of 12 perennial accessions of $\mathrm{V}$. radiata ssp. sublobata for early- and late-summer sowings in SE Queensland

The harvest indices for seed $\left(\mathrm{HI}_{\text {seed }}\right)$ and tuber $\left(\mathrm{HI}_{\text {tuber }}\right)$ are the respective proportions of these components in the recovered total plant biomass, which excludes finer roots and fallen leaves. - Indicates not measured. Data are means across replicates in each sowing

\begin{tabular}{|c|c|c|c|c|c|c|c|}
\hline Accession & Date of sowing & $\begin{array}{l}\text { Seed biomass } \\
\qquad\left(\mathrm{g} / \mathrm{m}^{2}\right)\end{array}$ & $\begin{array}{l}\text { Tuber biomass } \\
\qquad\left(\mathrm{g} / \mathrm{m}^{2}\right)\end{array}$ & $\begin{array}{l}\text { Recovered total } \\
\text { biomass } \\
\left(\mathrm{g} / \mathrm{m}^{2}\right)\end{array}$ & $\begin{array}{l}\mathrm{HI}_{\text {seed }} \\
(\%)\end{array}$ & $\begin{array}{l}\mathrm{HI}_{\text {tuber }} \\
(\%)\end{array}$ & $\begin{array}{c}\text { Tuber protein } \\
\text { content } \\
(\% \mathrm{w} / \mathrm{w})\end{array}$ \\
\hline \multirow[t]{2}{*}{ ACC 2} & 15 Dec. & 28.8 & 80.4 & 355 & 8.0 & 23.0 & - \\
\hline & 16 Feb. & 1.4 & 19.3 & 239 & 1.0 & 8.0 & 11.1 \\
\hline Mean over dates & & 15.1 & 49.9 & 297 & 4.5 & 15.5 & \\
\hline \multirow[t]{2}{*}{ ACC 3} & 15 Dec. & 21.7 & 64.8 & 318 & 7.0 & 21.0 & - \\
\hline & 16 Feb. & 1.8 & 22.0 & 252 & 1.0 & 9.0 & 12.9 \\
\hline Mean over dates & & 11.8 & 43.4 & 285 & 4.0 & 15.0 & \\
\hline \multirow[t]{2}{*}{ ACC 22} & 15 Dec. & 20.0 & 96.9 & 315 & 6.0 & 31.0 & - \\
\hline & 16 Feb. & 0.3 & 12.3 & 200 & 0.0 & 6.0 & 10.8 \\
\hline Mean over dates & & 10.2 & 54.6 & 258 & 3.0 & 18.5 & \\
\hline \multirow[t]{2}{*}{ ACC 25} & 15 Dec. & 32.3 & 85.0 & 347 & 9.0 & 24.0 & - \\
\hline & 16 Feb. & 0.0 & 3.3 & 142 & 0.0 & 2.0 & - \\
\hline Mean over dates & & 16.2 & 44.2 & 245 & 4.5 & 13.0 & \\
\hline \multirow[t]{2}{*}{ ACC 26} & 15 Dec. & 34.8 & 97.8 & 409 & 9.0 & 24.0 & - \\
\hline & 16 Feb. & 0.0 & 5.3 & 231 & 0.0 & 2.0 & - \\
\hline Mean over dates & & 17.4 & 51.6 & 320 & 4.5 & 13.0 & \\
\hline \multirow[t]{2}{*}{ ACC 30} & 15 Dec. & 24.8 & 68.0 & 338 & 7.0 & 20.0 & - \\
\hline & 16 Feb. & 0.3 & 8.0 & 219 & 0.0 & 4.0 & 13.7 \\
\hline Mean over dates & & 12.6 & 38.0 & 279 & 3.5 & 12.0 & \\
\hline \multirow[t]{2}{*}{ ACC 87} & 15 Dec. & 17.3 & 65.5 & 316 & 5.0 & 21.0 & - \\
\hline & 16 Feb. & 0.0 & 9.2 & 204 & 0.0 & 5.0 & 13.8 \\
\hline Mean over dates & & 8.7 & 37.4 & 260 & 2.5 & 13.0 & \\
\hline \multirow[t]{2}{*}{ ACC 88} & 15 Dec. & 22.9 & 17.5 & 250 & 9.0 & 7.0 & - \\
\hline & 16 Feb. & 0.2 & 3.6 & 195 & 0.0 & 2.0 & - \\
\hline Mean over dates & & 11.6 & 10.6 & 223 & 4.5 & 4.5 & \\
\hline \multirow[t]{2}{*}{ ACC 89} & 15 Dec. & 29.0 & 39.1 & 347 & 8.0 & 11.0 & - \\
\hline & 16 Feb. & 0.4 & 12.2 & 198 & 0.0 & 6.0 & - \\
\hline Mean over dates & & 14.7 & 25.7 & 273 & 4.0 & 8.5 & \\
\hline \multirow[t]{2}{*}{ ACC 90} & 15 Dec. & 24.1 & 46.1 & 293 & 8.0 & 16.0 & - \\
\hline & 16 Feb. & 0.9 & 3.2 & 119 & 1.0 & 3.0 & 10.8 \\
\hline Mean over dates & & 12.5 & 24.7 & 206 & 4.5 & 9.5 & \\
\hline \multirow[t]{2}{*}{ ACC 91} & 15 Dec. & 18.8 & 129.2 & 411 & 5.0 & 31.0 & - \\
\hline & 16 Feb. & 0.0 & 18.0 & 232 & 0.0 & 8.0 & - \\
\hline Mean over dates & & 9.4 & 73.6 & 322 & 2.5 & 19.5 & \\
\hline \multirow[t]{2}{*}{ ACC 92} & 15 Dec. & 45.9 & 53.1 & 322 & 14.0 & 16.0 & - \\
\hline & 16 Feb. & 0.0 & 6.6 & 189 & 0.0 & 3.0 & 11.5 \\
\hline Mean over dates & & 23.0 & 29.9 & 256 & 7.0 & 9.5 & \\
\hline \multirow[t]{2}{*}{ Date means } & 15 Dec. & 26.7 & 70.3 & 335 & 7.9 & 20.4 & - \\
\hline & 16 Feb. & 0.4 & 10.3 & 202 & 0.3 & 4.8 & - \\
\hline Overall mean & & 13.6 & 40.3 & 268 & 4.1 & 12.6 & - \\
\hline \multicolumn{8}{|c|}{ Standard errors of differences between: } \\
\hline \multicolumn{2}{|c|}{ Accessions } & $3.2^{* *}$ & $10.9^{* *}$ & $28.9^{* *}$ & $0.29^{* *}$ & $0.94^{* *}$ & - \\
\hline \multicolumn{2}{|c|}{ Sowing dates } & $1.3^{* *}$ & $4.4^{* *}$ & $11.8^{* *}$ & $0.12^{* *}$ & $0.38^{* *}$ & - \\
\hline \multicolumn{2}{|c|}{ Accessions within sowing dates } & $4.6^{* *}$ & $15.4^{* *}$ & $40.8^{* *}$ & $0.41^{* *}$ & $1.32^{* *}$ & - \\
\hline
\end{tabular}

** $P \leq 0.01$

time in an adjacent serial sowing study suggested differential responses in seed production (Table 5).

On average, the perennial accessions produced significantly $(P<0.001)$ less seed biomass when sown on 15 December than the annual accessions sown at the same time (Table 5), although the proportion of total biomass partitioned into seed was similar for the 2 groups. Later sowing reduced seed yields in both the annual and the perennial growth types, but relatively less so in the annual types. However, the reduced partitioning of biomass into seed in the perennial forms at the later sowing was compensated by the accumulation of $\sim 5 \%$ of biomass in tuberised roots (cf. Table 4). Thus the proportion invested in 'regenerative' biomass (i.e. seeds + tubers) in the perennial accessions (Table 4) was more than double that invested in seed alone by the annual accessions (Table 5). 


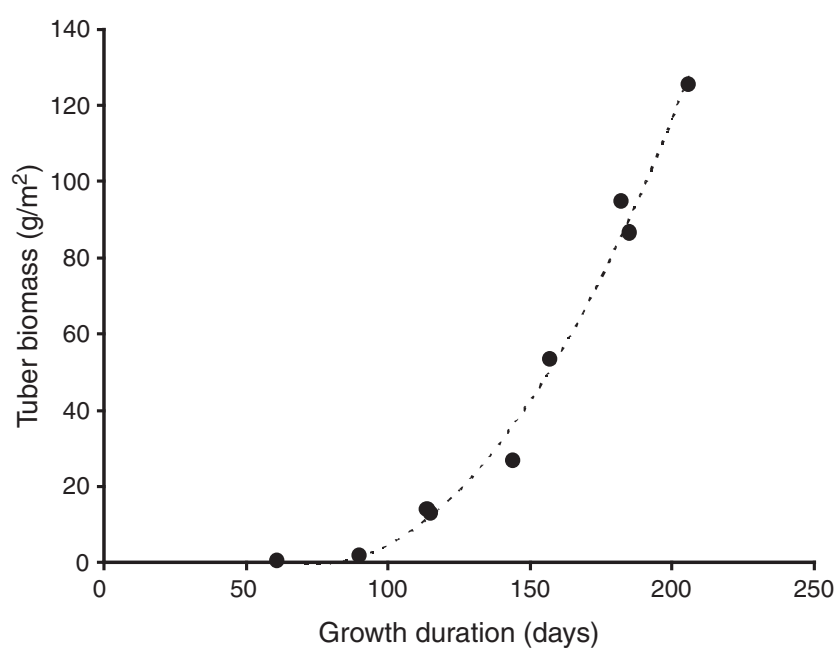

Fig. 3. Relationship between the duration of the growth cycle and the accumulated tuber biomass for the perennial $V$. radiata ssp. sublobata accession ACC 87, for 9 sowing dates in south-eastern Queensland. The equation for the fitted least squares relation is given by $y=39.6-1.084 x+0.0073 x^{2}\left(R^{2}=0.99^{* *}\right)$. Data from the study of Rebetzke and Lawn (2006b).

Table 5. Comparison of mean seed yield and seed harvest index $\left(\mathrm{HI}_{\text {seed }}\right)$ for the 12 perennial accessions in the present study with those for similar sowings of 10 annual accessions of $\boldsymbol{V}$. radiata ssp. sublobata

The annual forms were collected from a range of geographic locations and grown in a serial sowing study at the same location as the present study (see Rebetzke and Lawn $2006 b$ for details)

\begin{tabular}{|c|c|c|c|c|}
\hline \multirow[t]{3}{*}{ Growth cycle } & \multicolumn{4}{|c|}{ Sowing date } \\
\hline & \multicolumn{2}{|c|}{15 December } & \multicolumn{2}{|c|}{16 February } \\
\hline & $\begin{array}{l}\text { Seed } \\
\text { biomass } \\
\left(\mathrm{g} / \mathrm{m}^{2}\right)\end{array}$ & $\begin{array}{c}\mathrm{HI}_{\text {seed }} \\
(\%)\end{array}$ & $\begin{array}{l}\text { Seed } \\
\text { biomass } \\
\left(\mathrm{g} / \mathrm{m}^{2}\right)\end{array}$ & $\begin{array}{c}\mathrm{HI}_{\text {seed }} \\
(\%)\end{array}$ \\
\hline Annual & 33.2 & $8.0^{\mathrm{A}}$ & 2.2 & $2.0^{\mathrm{A}}$ \\
\hline Perennial & 26.7 & $7.9^{\mathrm{B}}$ & 0.4 & $0.3^{\mathrm{B}}$ \\
\hline $\begin{array}{l}\text { Standard errors of } \\
\text { differences between } \\
\text { growth cycle types } \\
\text { within sowing dates }\end{array}$ & $1.3^{* *}$ & 0.3 n.s. & 1.3 n.s. & $0.3^{* *}$ \\
\hline
\end{tabular}

** $P \leq 0.01$; n.s., not significant.

${ }^{\mathrm{A}}$ Excludes root biomass.

${ }^{\mathrm{B}}$ Includes tuber biomass.

The limited measurements of protein content taken in the second sowing (Table 4) indicated that on a dry weight basis, the protein content of the thickened tap and lateral roots averaged $12 \%$. The observed concentrations were not as large as recorded for some tuberous legumes but are at least twice those reported for commonly grown non-leguminous root crops (Anon. 1979).

\section{Summary and possible adaptive significance}

The gross morphology of the root system of the 12 perennial accessions differed substantially from the normal fine, fibrous root system of annual accessions of wild and cultivated mungbean. However, the differences in root morphology between the perennial accessions were relatively small. All developed a thickened tap root to a depth of $0.20-0.30 \mathrm{~m}$, and thickened lateral roots that emerged from the taproot near the soil surface. The thickened side roots extended laterally for up to $1100 \mathrm{~mm}$ from the plant, remaining close to the soil surface.

There were statistically significant differences among accessions in tuber, seed, and total plant biomass production. Among the accessions, average tuber biomass production, but not seed production, was positively correlated with recovered total plant biomass. On average, tuber biomass represented $12.6 \%$ of total plant biomass at pod maturity, compared with only $4.4 \%$ for seed biomass. Among accessions, the trend was for accessions with higher proportions of tuber biomass to have lower proportions of seed biomass.

All but one of the perennial accessions were collected in the Townsville-Charters Towers region. This apparent discrete distribution of the perennial accessions, combined with their general morphological similarity, suggests that the accessions are part of a local geographic population, which shares a unique growth habit and generally similar phenologies.

The region where the accessions were collected is part of the seasonally arid tropics. Most of the rainfall (85-90\%) occurs during the wet season, December-March, with only sporadic showers during the long dry season (April-November). The predominant habitat where the wild mungbean is found is lightly to moderately wooded savannah grassland, dominated in the natural state by eucalypts and the perennial grasses, speargrass (Heteropogon contortus) and kangaroo grass (Themeda triandra). The area is susceptible to fire especially during the dry season, and most of the woody and herbaceous species are well adapted to a fire regime.

Although the ecological significance of the trait remains conjectural, it is possible that the development of the perennial trait in wild mungbean was favoured by fire. In the absence of fire, some of the above-ground stems remain alive over the dry season, to give rise to new re-growth after the first summer rains. In these situations, competition from the dominant grasses is strong. However, where fire during the dry season has removed the aboveground biomass, the perennial mungbean regenerates from the below-ground adventitious buds that develop on the thickened taproot and shallow thickened laterals (Fig. 2b,c). In these situations, the re-growth is more vigorous than in the absence of fire, perhaps because of reduced initial competition from the grasses.

Alternatively or perhaps additionally, the tendency to divert more reproductive effort into tuber than seed biomass may reflect an adaptive response to seed predation. Field observation indicates that seed predation by a range of 
organisms including pod-sucking and pod-chewing insects, seed-eating birds (especially parrots), and marsupials, is prevalent.

There is historical evidence that the existence of tuberous rooted ecotypes of wild mungbean in the Townsville region was known to the local Aborigines and that the tubers were used as 'bush tucker'. A report by the 19th century botanist Anthelme Thozet stated that 'the Cleveland Bay natives' baked the thickened roots of Phaseolus mungo L. for food (Thozet 1866). Although Phaseolus mungo L. (sensu stricto) does not occur naturally in Australia, the name was a common misnomer for V. radiata ssp. sublobata in the 19th Century (e.g. Bentham and Mueller 1864).

Some of the perennial accessions used in this study were among those shown to hybridise readily with the cultivated mungbean (James et al. 1999). However, the inheritance of the perennial trait has not yet been established. In the context of modern agriculture, it is unlikely that the perennial trait would be of immediate interest for development of commercial mungbean cultivars, given the low propensity of the perennial accessions to produce seed.

However, it is possible that the perennial accessions could be of interest for development as a forage legume adapted to the seasonally arid coastal and subcoastal grasslands of northern Australia. The invasive spread of exotic pasture species into non-pastoral areas has led to concerns about their effect on natural ecosystems (e.g. Lonsdale 1994). As part of the existing natural system, the perennial wild mungbean would avoid many of these environmental concerns. Even improved varieties specifically bred for enhanced productivity in managed forage or grazing systems would be of minimal concern, since escapes would likely fail to persist or would rapidly revert to wild type though introgression with the naturally occurring wild forms.

\section{Acknowledgments}

The research reported here was supported by the Grains Research and Development Corporation and the CSIRO Division of Tropical Crops and Pastures, and was undertaken in partial fulfillment of the requirements of the MAgrSc degree awarded to GJR by the University of Queensland.

\section{References}

Alvarenga AA, Valio IF (1989) Influence of temperature and photoperiod on flowering and tuberous root formation of Pachyrrhizus tuberosus. Annals of Botany 64, 411-414.

Anon. (1979) 'Tropical legumes: Resources for the future.' (National Academy of Science: Washington, DC)

Bentham G, Mueller F (1864) 'Flora Australiensis. A description of the plants of the Australian Territory. II. Leguminosae to Commbretaceae.' (Lovell Reeve \& Co: Covent Garden, London)
Grant T, Lawn RJ, Bielig LM (2003) Variation among Australian accessions of Vigna vexillata for traits of agronomic, adaptive or taxonomic interest. Australian Journal of Agricultural Research 54, 243-250. doi: 10.1071/AR02147

James AT, Lawn RJ, Williams RW, Lambrides CJ (1999) Cross fertility of Australian accessions of wild mungbean (Vigna radiata ssp. sublobata) with green gram ( $V$. radiata $\mathrm{ssp}$. radiata) and black gram (V. mungo). Australian Journal of Botany 47, 601-610. doi: $10.1071 / \mathrm{BT} 97068$

Lawn RJ, Cottrell A (1988) Wild mungbean and its relatives in Australia. Biologist 35, 267-273.

Lawn RJ, Holland AE (2003) Variation in the Vigna lanceolata Benth. complex for traits of taxonomic, adaptive or agronomic interest. Australian Journal of Botany 51, 295-308. doi: 10.1071/BT02105

Lawn RJ, Rebetzke GJ (2006) Variation among Australian accessions of the wild mungbean (Vigna radiata ssp. sublobata) for traits of agronomic, adaptive or taxonomic interest. Australian Journal of Agricultural Research 57, 119-132. doi: 10.1071/AR05215

Lawn RJ, Watkinson AR (2002) Habitat, morphological diversity and distribution of the genus Vigna Savi in Australia. Australian Journal of Agricultural Research 53, 1305-1316. doi: 10.1071/AR02065

Lonsdale WM (1994) Inviting trouble: introduced pasture species in northern Australia. Australian Journal of Ecology 19, 345-354.

Milthorpe FL (1967) Some physiological principles determining the yield of root crops. In 'Proceedings of the International Symposium on Tropical Root Crops. Vol. 1'. (Eds EA Tai, WE Charles, EF Iton, PH Haynes, KA Leaslie) pp. 1-15.

Paull RE, Chen NJ, Fukuda SK (1988) Planting dates related to tuberous root yield, vine length and quality attributes in yam bean. HortScience 23, 326-329.

Rebetzke GJ (1994) Attributes of potential adaptive and agronomic significance in the wild mungbean (Vigna radiata (L.) ssp. sublobata (Roxb.) Verdc.). MAgric.Sc thesis, The University of Queensland, Australia.

Rebetzke GJ, Lawn RJ (2006a) Adaptive responses of wild mungbean (Vigna radiata ssp. sublobata) to photo-thermal environment. I. Phenology. Australian Journal of Agricultural Research 57, (In press).

Rebetzke GJ, Lawn RJ (2006b) Adaptive responses of wild mungbean (Vigna radiata ssp. sublobata) to photo-thermal environment. II. Growth, biomass, and seed yield. Australian Journal of Agricultural Research 57, (In press).

Rundel PW (1983) Fire as an ecological factor. In 'Encyclopaedia of physiological plant ecology. Vol. 12A'. (Eds OL Lange, PS Nobel, CB Osmond, H Zeigler) pp. 501-538. (Springer-Verlag: Berlin)

Smartt J, Hymowitz T (1985) Domestication and evolution of grain legumes. In 'Grain legume crops'. (Eds RJ Summerfield, EH Roberts) pp. 37-72. (Collins: London)

Sobulo RA (1972) Studies on white yam (Dioscera rotundata). I. Growth analysis. Experimental Agriculture 8, 99-106.

Thozet A (1866) 'Notes on some of the roots, tubers, bulbs and fruits used as vegetable food by the Aboriginals of Northern Queensland, Australia.' (JH Buzacott, 'Bulletin' Office: Rockhampton, Qld.)

Manuscript received 17 October 2005, accepted 2 March 2006 